\title{
School grounds soil contamination with heavy metals and arsenic compounds in the city of Vladimir
}

\author{
Oleg Selivanov ${ }^{1, *}$ and Anton Martsev ${ }^{1}$ \\ ${ }^{1}$ Vladimir State University named after A.G. and N.G. Stoletovs', Gorky Street 87, 600000, Vladimir, \\ Russia
}

\begin{abstract}
The article presents the content determining results of heavy metals and arsenic in sod-podzolic soils of the school grounds in Vladimir, Vladimir region. According to the accumulation indicator, the accumulation intensity of heavy metals and arsenic in these areas has been determined, which is decreasing in the series of $\mathrm{Pb} \rightarrow \mathrm{As} \rightarrow \mathrm{Cu} \rightarrow \mathrm{Zn} \rightarrow \mathrm{Ni}$. The calculation of the pollutants hazard coefficient showed that their MPC excess decreases in the series of $\mathrm{As} \rightarrow \mathrm{Zn} \rightarrow \mathrm{Pb} \rightarrow \mathrm{Cu} \rightarrow \mathrm{Ni}$. The soil pollution level has been assessed for the school grounds and their ecological situation has been evaluated applying the cumulative indicator of soil pollution with heavy metals and soil pollution index. The values of the soil pollution cumulative indicator of school territories indicate dangerous and moderately dangerous contamination level of the studied soils, and the calculated values of the soil pollution index refer these soils to the category of "contaminated" soils, which poses potential risks for the schoolchildren health.
\end{abstract}

\section{Introduction}

The anthropogenic process contributes to the chemozems formation in urban landscapes chemically contaminated soils with heavy metal (HM) compounds and arsenic, which content exceeds the actual environmental standards. The most hazardous soil pollutants of industrial cities in Russia are HM compounds, which get into the soil with gas and dust emissions from industrial and heat-power enterprises, as well as exhaust gases from motor vehicles [1-4].

Most HM are characterized by low mobility and high accumulating capacity in living organisms and depositing media (soils, bottom sediments), thus causing their intensive accumulation and long-term storage [5-7].

HM salts affect soil microflora and microfauna, its biochemical processes are suppressed, the vegetation in the area deteriorates, producing negative impact on the population health living here [8-11]. The risk of soil contamination with high concentrations of HM determines the possibility of secondary air pollution with soil dust

*Corresponding author: selivanov6003@mail.ru 
[12]. Therefore, the study of urbanized territories for determining their ecological status is an urgent challenge.

According to our own data [13] and the data of the Department of Nature Management and Environmental Protection of the Vladimir Region Administration [14], Vladimir is one of the cities of the region, which air basin is annually subjected to serious load from industrial enterprises. Soil is polluted basically through the gas and dust emissions from vehicles and enterprises of the city. The waste from machine-building complex, some piled at the enterprises sites, and some - at the industrial waste landfills are an additional threat to the soil condition. Nowadays, the possibility of recycling waste, containing heavy metals, has been studied [15-16], but the threat of pollution to the environment, including soil, still remains relevant.

Research objective is to assess soil contamination level with HM compounds and arsenic of the school grounds in Vladimir.

\section{Research objects and methods}

The research object was the sod-podzolic soil of 15 city school grounds located in three districts of Vladimir city. The soil samples from school grounds were taken from the 0-10 $\mathrm{cm}$ horizon by the envelope method in three repetitions.

Heavy metals and arsenic (Ci) content was determined by X-ray fluorescence method applying the spectrometer "SPECTROSCAN MAX-G" in compliance with the Federal Standard PND F 16.1.42-04.

To assess the soil contamination level by pollutants, the accumulation index (Ia), the hazard coefficient $(\mathrm{Ch})$, the cumulative pollution index $(\mathrm{Zc})$ and the soil contamination index (SCI) have been used.

The accumulation index (Ia) of HM and arsenic was calculated using the formula 1:

$$
I a=\frac{\mathrm{C} i-\mathrm{Cb}}{\mathrm{C} b}
$$

where $\mathrm{Ci}$ - metal and arsenic concentration in soil, $\mathrm{mg} / \mathrm{kg}$;

$\mathrm{Cb}$ - background content of HM and arsenic in soil, $\mathrm{mg} / \mathrm{kg}$

Background concentrations of HM and arsenic in soil are taken from the research [17].

The hazard coefficient of HM and arsenic was calculated using the formula 2:

$$
C_{h}=\frac{C i}{M P C i} ;
$$

where $\mathrm{Ci}$ - concentration of metal and arsenic in the soil, $\mathrm{mg} / \mathrm{kg}$;

MPCi - maximum permissible concentration of $\mathrm{HM}$ and arsenic in soil, $\mathrm{mg} / \mathrm{kg}$

The maximum permissible concentrations for HM and arsenic in soil (MPCi) are taken from The Standard GN 2.1.7.020-94.

The characteristics of the soil contamination level by the pollutants and environmental situation assessment of the school grounds have been carried out by calculating the cumulative pollution index (Zc) and HM soil contamination index ( $\mathrm{SCI}$ ), allowing to differentiate the areas according to the hazard degree in sanitary aspect.

The cumulative pollution index $(\mathrm{Zc})$ equals the sum of concentration coefficients of chemical elements-pollutants and is expressed by the formula 3 :

$$
Z c=\sum_{K c i}-(n-1)
$$

where $\mathrm{n}$ - number of the determined summed substances;

Kci - concentration coefficient of the i-th pollution component, calculated by the formula 4: 


$$
K c i=\frac{\mathrm{C} i}{\mathrm{Cb}}
$$

The soil contamination index (SCI) was calculated by the formula 5:

$$
S C I=\sum(C h) / n
$$

where $\mathrm{Ch}$ - hazard coefficient;

$\mathrm{n}$ - fixed amount of ingredients on the surveyed area.

Statistical data was processed applying the program "Statistica".

\section{Results and discussion}

The soil at school grounds was analyzed for the following chemical elements content: As, $\mathrm{Cu}, \mathrm{Ni}, \mathrm{Pb}, \mathrm{Zn}$. These elements content increases in the following series: $\mathrm{As} \rightarrow \mathrm{Ni} \rightarrow \mathrm{Cu} \rightarrow \mathrm{Pb} \rightarrow \mathrm{Zn}$. The toxicants content in the soil of school grounds is presented in Table 1.

\begin{tabular}{|c|c|c|c|c|c|c|c|c|}
\hline \multirow{2}{*}{$\mathrm{HM}$} & \multicolumn{8}{|c|}{ School \# and HM and arsenic concentration in soil, $\mathrm{mg} / \mathrm{kg}$} \\
\hline & 1 & 2 & 6 & 9 & 10 & 11 & 13 & 15 \\
\hline $\mathrm{Pb}$ & $\begin{array}{l}99.3 \\
\pm 6.1\end{array}$ & $\begin{array}{l}37.9 \\
\pm 6.6\end{array}$ & $\begin{array}{c}102.9 \\
\pm 6.2\end{array}$ & $\begin{array}{l}99.6 \\
\pm 6.7\end{array}$ & $\begin{array}{l}32.3 \\
\pm 6.5\end{array}$ & $\begin{array}{c}192.7 \\
\pm 7.1\end{array}$ & $\begin{array}{c}103.7 \\
\pm 6.5\end{array}$ & $\begin{array}{l}51.5 \\
\pm 5.9\end{array}$ \\
\hline As & $\begin{array}{l}17.7 \\
\pm 1.4\end{array}$ & $\begin{array}{c}8.0 \\
\pm 1.6\end{array}$ & $\begin{array}{l}17.5 \\
\pm 1.4\end{array}$ & $\begin{array}{l}16.5 \\
\pm 1.6\end{array}$ & $\begin{array}{c}8.8 \\
\pm 1.5\end{array}$ & $\begin{array}{l}33.5 \\
\pm 1.6\end{array}$ & $\begin{array}{l}20.9 \\
\pm 1.5\end{array}$ & $\begin{array}{l}10.8 \\
\pm 1.4\end{array}$ \\
\hline $\mathrm{Zn}$ & $\begin{array}{c}415.5 \\
\pm 4.3\end{array}$ & $\begin{array}{c}112.9 \\
\pm 2.4\end{array}$ & $\begin{array}{c}239.0 \\
\pm 3.0\end{array}$ & $\begin{array}{c}118.5 \\
\pm 2.4\end{array}$ & $\begin{array}{l}69.9 \\
\pm 2.1\end{array}$ & $\begin{array}{c}365.0 \\
\pm 4.2\end{array}$ & $\begin{array}{c}193.7 \\
\pm 2.9\end{array}$ & $\begin{array}{c}137.7 \\
\pm 2.3\end{array}$ \\
\hline $\mathrm{Cu}$ & $\begin{array}{l}49.0 \\
\pm 2.4\end{array}$ & $\begin{array}{l}69.1 \\
\pm 2.8\end{array}$ & $\begin{array}{l}58.4 \\
\pm 2.5\end{array}$ & $\begin{array}{l}64.0 \\
\pm 2.7\end{array}$ & $\begin{array}{l}47.0 \\
\pm 2.7\end{array}$ & $\begin{array}{l}74.3 \\
\pm 2.9\end{array}$ & $\begin{array}{l}46.2 \\
\pm 2.6\end{array}$ & $\begin{array}{l}42.0 \\
\pm 2.4\end{array}$ \\
\hline $\mathrm{Ni}$ & $\begin{array}{l}18.5 \\
\pm 2.2\end{array}$ & $\begin{array}{l}46.0 \\
\pm 2.6\end{array}$ & $\begin{array}{l}32.5 \\
\pm 2.3\end{array}$ & $\begin{array}{l}29.8 \\
\pm 2.5\end{array}$ & $\begin{array}{l}29.3 \\
\pm 2.5\end{array}$ & $\begin{array}{l}35.6 \\
\pm 2.6\end{array}$ & $\begin{array}{l}40.0 \\
\pm 2.5\end{array}$ & $\begin{array}{l}26.3 \\
\pm 2.2\end{array}$ \\
\hline & 16 & 26 & 36 & 38 & 39 & 41 & 45 & $\begin{array}{c}\text { average } \\
\text { value }\end{array}$ \\
\hline $\mathrm{Pb}$ & $\begin{array}{l}77.4 \\
\pm 6.1\end{array}$ & $\begin{array}{l}79.7 \\
\pm 6.3\end{array}$ & $\begin{array}{l}39.5 \\
\pm 6.2\end{array}$ & $\begin{array}{l}36.3 \\
\pm 6.6\end{array}$ & $\begin{array}{l}46.6 \\
\pm 6.1\end{array}$ & $\begin{array}{l}44.6 \\
\pm 6.1\end{array}$ & $\begin{array}{l}65.9 \\
\pm 6.4\end{array}$ & 73.99 \\
\hline As & $\begin{array}{l}14.9 \\
\pm 1.4\end{array}$ & $\begin{array}{l}15.6 \\
\pm 1.5\end{array}$ & $\begin{array}{c}9.1 \\
\pm 1.5\end{array}$ & $\begin{array}{c}6.0 \\
\pm 1.6\end{array}$ & $\begin{array}{l}10.0 \\
\pm 1.4\end{array}$ & $\begin{array}{c}8.7 \\
\pm 1.4\end{array}$ & $\begin{array}{l}13.7 \\
\pm 1.5\end{array}$ & 14.11 \\
\hline $\mathrm{Zn}$ & $\begin{array}{l}145.6 \\
\pm 2.4 \\
\end{array}$ & $\begin{array}{c}282.6 \\
\pm 3.5 \\
\end{array}$ & $\begin{array}{c}100.6 \\
\pm 2.2 \\
\end{array}$ & $\begin{array}{l}95.7 \\
\pm 2.2 \\
\end{array}$ & $\begin{array}{l}93.5 \\
\pm 2.1 \\
\end{array}$ & $\begin{array}{c}127.1 \\
\pm 2.3 \\
\end{array}$ & $\begin{array}{c}136.3 \\
\pm 2.5 \\
\end{array}$ & 175.57 \\
\hline $\mathrm{Cu}$ & $\begin{array}{l}48.0 \\
\pm 2.5\end{array}$ & $\begin{array}{l}56.9 \\
\pm 2.6\end{array}$ & $\begin{array}{l}54.3 \\
\pm 2.6\end{array}$ & $\begin{array}{l}71.4 \\
\pm 2.8\end{array}$ & $\begin{array}{l}56.3 \\
\pm 2.5\end{array}$ & $\begin{array}{l}51.5 \\
\pm 2.5\end{array}$ & $\begin{array}{l}56.3 \\
\pm 2.6\end{array}$ & 56.31 \\
\hline $\mathrm{Ni}$ & $\begin{array}{l}33.2 \\
\pm 2.3\end{array}$ & $\begin{array}{l}40.7 \\
\pm 2.4\end{array}$ & $\begin{array}{l}29.8 \\
\pm 2.4\end{array}$ & $\begin{array}{l}40.9 \\
\pm 2.6\end{array}$ & $\begin{array}{l}31.6 \\
\pm 2.3\end{array}$ & $\begin{array}{l}29.5 \\
\pm 2.3\end{array}$ & $\begin{array}{l}23.1 \\
\pm 2.4\end{array}$ & 32.45 \\
\hline
\end{tabular}

Table 1. HM and arsenic content in the studied soil samples from school grounds.

To identify the priority soil pollutants at school areas, the accumulation index (Ai) was used (Table 2).

The indicator of the pollutants accumulation in the studied soil decreases in the series: $\mathrm{Pb} \rightarrow \mathrm{As} \rightarrow \mathrm{Cu} \rightarrow \mathrm{Zn} \rightarrow \mathrm{Ni}$. 
To assess the contamination level of the soil cover at school territories by certain pollutants, the hazard coefficients $(\mathrm{Ch})$ has been calculated for each pollutant (Table 3 ).

Table 2. Accumulation index (Ai) of HM and arsenic in the soil from school grounds of Vladimir.

\begin{tabular}{|c|c|r|r|r|r|r|r|r|}
\hline & \multicolumn{6}{|c|}{ School \# and accumulation index of HM and arsenic in the soil from their } \\
\cline { 2 - 10 } $\mathrm{HM}$ & 1 & 2 & \multicolumn{1}{c|}{6} & \multicolumn{1}{c|}{9} & \multicolumn{1}{c|}{10} & \multicolumn{1}{c|}{11} & \multicolumn{1}{c|}{13} & \multicolumn{1}{c|}{15} \\
\hline $\mathrm{Pb}$ & 15.55 & 5.32 & 16.15 & 15.60 & 4.38 & 31.12 & 16.28 & 7.58 \\
\hline $\mathrm{As}$ & 10.80 & 4.33 & 10.67 & 10.00 & 4.87 & 21.33 & 12.93 & 6.20 \\
\hline $\mathrm{Zn}$ & 13.84 & 3.03 & 7.54 & 3.23 & 1.50 & 12.04 & 5.92 & 3.92 \\
\hline $\mathrm{Cu}$ & 5.13 & 7.64 & 6.30 & 7.00 & 4.88 & 8.29 & 4.78 & 4.25 \\
\hline $\mathrm{Ni}$ & 2.08 & 6.67 & 4.42 & 3.97 & 3.88 & 4.93 & 5.67 & 3.38 \\
\hline & 16 & 26 & 36 & 38 & 39 & 41 & 45 & $\begin{array}{l}\text { average } \\
\text { value }\end{array}$ \\
\hline $\mathrm{Pb}$ & 11.90 & 12.28 & 5.58 & 5.05 & 6.77 & 6.43 & 9.98 & 11.33 \\
\hline $\mathrm{As}$ & 8.93 & 9.40 & 5.07 & 3.00 & 5.67 & 4.80 & 8.13 & 8.41 \\
\hline $\mathrm{Zn}$ & 4.20 & 9.09 & 2.59 & 2.42 & 2.34 & 3.54 & 3.87 & 5.27 \\
\hline $\mathrm{Cu}$ & 5.00 & 6.11 & 5.79 & 7.93 & 6.04 & 5.44 & 6.04 & 6.04 \\
\hline $\mathrm{Ni}$ & 4.53 & 5.78 & 3.97 & 5.82 & 4.27 & 3.92 & 2.85 & 4.41 \\
\hline
\end{tabular}

The pollutants excess regarding MPC decreases in the series: $\mathrm{As} \rightarrow \mathrm{Zn} \rightarrow \mathrm{Pb} \rightarrow \mathrm{Cu} \rightarrow \mathrm{Ni}$.

Further soil contamination index (SCI) was calculated, which is based on the normative indicators (maximum and approximate permissible concentrations of substances - MPC and UEC, respectively), allowing to differentiate the area according to the sanitary hazard degree for living there. The soil contamination index divides polluted soils into the categories: at $<0.75$ - clean, $0.75-1.0$ - problematic, and at SCI $>1$ - contaminated.

Table 3. Hazard coefficients (Ch) of HM and arsenic in soil of Vladimir city.

\begin{tabular}{|c|c|c|c|c|c|c|c|c|}
\hline \multirow{2}{*}{$\mathrm{HM}$} & \multicolumn{6}{|c|}{ School \# and hazard coefficient (Ko) of HM and arsenic in soil of the area } \\
\cline { 2 - 9 } & 1 & 2 & 6 & 9 & 10 & 11 & 13 & 15 \\
\hline $\mathrm{Pb}$ & 3.10 & 1.18 & 3.22 & 3.11 & 1.01 & 6.02 & 3.24 & 1.61 \\
\hline $\mathrm{As}$ & 8.85 & 4.00 & 8.75 & 8.25 & 4.40 & 16.75 & 10.45 & 5.40 \\
\hline $\mathrm{Zn}$ & 7.55 & 2.05 & 4.35 & 2.15 & 1.27 & 6.64 & 3.52 & 2.50 \\
\hline $\mathrm{Cu}$ & 1.48 & 2.09 & 1.77 & 1.94 & 1.42 & 2.25 & 1.40 & 1.27 \\
\hline $\mathrm{Ni}$ & 0.93 & 2.30 & 1.63 & 0.92 & 1.47 & 1.78 & 2.00 & 1.32 \\
\hline & & & & & & & & average \\
\hline $\mathrm{Pb}$ & 2.42 & 2.49 & 1.23 & 1.13 & 1.46 & 1.39 & 2.06 & 2.31 \\
\hline $\mathrm{As}$ & 7.45 & 7.80 & 4.55 & 3.00 & 5.00 & 4.35 & 6.85 & 7.06 \\
\hline $\mathrm{Zn}$ & 2.65 & 5.14 & 1.83 & 1.74 & 1.70 & 2.31 & 2.48 & 3.19 \\
\hline $\mathrm{Cu}$ & 1.45 & 1.72 & 1.65 & 2.16 & 1.71 & 1.56 & 1.71 & 1.71 \\
\hline $\mathrm{Ni}$ & 1.66 & 2.04 & 1.49 & 2.05 & 1.58 & 1.48 & 1.16 & 1.58 \\
\hline
\end{tabular}

Table 4 demonstrates the cumulative pollution index $(\mathrm{Zc})$ and soil contamination index (SCI) values of the school grounds of the Vladimir city with HM and arsenic, and the ecological situation category in the studied areas. 
Table 4. The cumulative indicator of soil contamination $(\mathrm{Zc})$ with $\mathrm{TM}$ and arsenic of the school grounds of Vladimir.

\begin{tabular}{|l|c|c|c|l|}
\hline \multicolumn{1}{|c|}{$\begin{array}{c}\text { Sampling } \\
\text { location }\end{array}$} & Zc & Contamination category & $S C I$ & \multicolumn{1}{|c|}{$\begin{array}{c}\text { Contamination } \\
\text { category }\end{array}$} \\
\hline School №1 & 48.4 & Hazardous & 4.38 & Contaminated \\
\hline School №2 & 27.99 & Moderate Hazardous & 2.33 & Contaminated \\
\hline School №6 & 46.07 & Hazardous & 3.94 & Contaminated \\
\hline School №9 & 40.8 & Hazardous & 3.39 & Contaminated \\
\hline School №10 & 20.5 & Moderate Hazardous & 1.91 & Contaminated \\
\hline School №11 & 78.7 & Hazardous & 6.69 & Contaminated \\
\hline School №13 & 46.58 & Hazardous & 4.12 & Contaminated \\
\hline School №15 & 26.33 & Moderate Hazardous & 2.42 & Contaminated \\
\hline School №16 & 35.57 & Hazardous & 3.13 & Contaminated \\
\hline School №26 & 43.67 & Hazardous & 3.84 & Contaminated \\
\hline School №36 & 24 & Moderate Hazardous & 2.15 & Contaminated \\
\hline School №38 & 25.21 & Moderate Hazardous & 2.02 & Contaminated \\
\hline School №39 & 26.08 & Moderate Hazardous & 2.16 & Contaminated \\
\hline School №41 & 25.13 & Moderate Hazardous & 2.22 & Contaminated \\
\hline School №45 & 31.87 & Moderate Hazardous & 2.85 & Contaminated \\
\hline
\end{tabular}

\section{Conclusion}

The research results demonstrated that $\mathrm{HM}$ and arsenic content in the school grounds soils increases in the series: $\mathrm{As} \rightarrow \mathrm{Ni} \rightarrow \mathrm{Cu} \rightarrow \mathrm{Pb} \rightarrow \mathrm{Zn}$. The indicator of the pollutants accumulation of the studied soils decreases in the series: $\mathrm{Pb} \rightarrow \mathrm{As} \rightarrow \mathrm{Cu} \rightarrow \mathrm{Zn} \rightarrow \mathrm{Ni}$.

The calculated values of the cumulative pollution index $(\mathrm{Zc})$ and soil contamination index (SCI) of the school territories of Vladimir city with TM and arsenic, received as research results, allow differentiating the school sites according to the hazard degree in the consequence of anthropogenic soil pollution.

\section{References}

1. H. Pan, X. Lu, K. Lei, Environmental Science and Pollution Research 25, 523-532, (2018) DOI: 10.1007/s11356-017-0467-3

2. A. Kabata-Pendias, H. Pendias, Trace Elements in Soils and Plants. Boca-Raton; London; New-York; Washington: CRC Press, 403 (2001)

3. T. A.Trifonova, A. A Podolets, O. G.;Selivanov, A. A. Martsev, A. A..Podolets, Theoretical and Applied Ecology 2, 94-101, (2018) DOI: 10.25750/1995-4301-20182-094-101/1 
4. T. A. Trifonova, A. A. Martsev, O. G.;Selivanov, Theoretical and Applied Ecology 4, 155-161 (2020) DOI: 10.25750/1995-4301-2020-4-155-161

5. I. F. Rivai Bulletin of Environ. Contamin. and Toxic. 66, 443-448, (2001)

6. M.N. Stroganova, A.D. Myagkova, T.V. Prokofieva Eurasian Soil Science 30, 82-86 (1997)

7. M. Lambert, B.A. Leven, R.M. Green Environmental science and technology briefs for citizens 2, 1-3 (2000)

8. A. Lehmann, K. Stahr J. of Soils \& Sediments 7, 247-260 (2007)

9. A. Martsev, O. Selivanov E3S Web of Conferences 135, 01047 (2019)

10. N. Adimalla, J. Chen, H. Qian, Ecotoxic. and Environm Safety 194, 110406 (2020)

11. E. Ramazanova, S.H. Lee, W. Lee Science of The Total Environment 750, 141535, (2021)

12. Q. Han, M. Wang, J. Cao, C. Gui, Y. Liu, X. He, Y. He, Y. Liu Ecotoxicology and Environmental Safety 191, 110157, (2020)

13. O. Selivanov, A. Martsev IOP Conference Series: Earth and Environmental Science 403 (1), 012170 (2019)

14. About the state of the environment and population's health Vladimir region in 2016: annual report of the mi. region, Department of natural resources and environmental protection. Vladimir: Transit-IKS, 118 (2017) (in Russian)

15. A. A. Vorob'eva, V. N. Shakhova, E. S. Pikalov, O. G. Selivanov, É. P. Sysoev, V.Y. Chukhlanov Glass and Ceramics 75, 51-54, (2018)

16. M. A Sukharnikova, E.S. Pikalov, O.G. Selivanov, É.P. Sysoev, V.Y Chukhlanov, Glass and Ceramics 73, 100-102 (2016)

17. The maximum permissible concentration (MPC) of substances in the soil. Hygienic standards GN 2.1.7.2041-6 Moskva: Consultant Plus (2008) (in Russian) 